\title{
Why do postgraduate students commit plagiarism? An empirical study
}

\author{
Apatsa Selemani ${ }^{*}$ (D), Winner Dominic Chawinga ${ }^{2}$ and Gift Dube ${ }^{3}$
}

\author{
* Correspondence: \\ aselemani@medcol.mw \\ ${ }^{1}$ College of Medicine Library, \\ University of Malawi, Blantyre, \\ Malawi \\ Full list of author information is \\ available at the end of the article
}

\begin{abstract}
The study investigated postgraduate students' knowledge of plagiarism, forms of plagiarism they commit, the reasons they commit plagiarism and actions taken against postgraduate students who plagiarise at Mzuzu University in Malawi. The study adopted a mixed methods approach. The quantitative data were collected by distributing questionnaires to postgraduate students and academic staff whereas qualitative data were collected by conducting follow-up interviews with some academics, an assistant registrar and assistant librarian. The study found that despite students reporting that they had a conceptual understanding of plagiarism, the majority of them reported that they had intentionally and unintentionally committed plagiarism, mainly due to pressure for good grades (86.7\%), laziness and poor time management (84.9\%), and lack of good academic writing skills (84.9\%). The study also established that prevalent forms of plagiarism admitted (by students) and reported (by academic staff) to have been committed included lack of proper acknowledgement after paraphrasing (69.8\%), summarising (64.1\%) and using quotation marks (56.6\%). The study further found that the common sanctions applied by academics include giving a warning and asking the student to re-write the plagiarised work. The study recommends that Mzuzu University should carry out awareness campaigns about the negative effects of plagiarism, targeting postgraduate students; and should introduce advanced academic writing skills training for postgraduate students.
\end{abstract}

Keywords: Malawi, Postgraduate students, Prevalence of plagiarism, Reasons for plagiarising, Sanctions against plagiarism

\section{Introduction}

One of the long-standing challenges faced by higher learning institutions is the issue of plagiarism among students. Its origins are said to be traced to as far as writing has existed (Park 2003). Despite the lack of a universally accepted definition of the word plagiarism, most of the definitions agree that plagiarism is premissed on the wrong use of the words and ideas of others. This paper adopted a definition by Ellis et al. (2018:1) who defined plagiarism as the practice of "presenting someone else's words and/or ideas as your own without appropriate attribution."

Plagiarism can be categorised as intentional or unintentional. Intentional plagiarism entails committing plagiarism with full knowledge of what constitutes plagiarism and how it can be prevented whereas unintentional plagiarism is committed inadvertently due to lack of knowledge and skills to avoid it (Mahmood et al. 2011). Plagiarism can

(C) The Author(s). 2018 Open Access This article is distributed under the terms of the Creative Commons Attribution 4.0 International License (http://creativecommons.org/licenses/by/4.0/), which permits unrestricted use, distribution, and reproduction in any medium, provided you give appropriate credit to the original author(s) and the source, provide a link to the Creative Commons license, and indicate if changes were made. 
take different forms including: "copy and paste" without quotes and acknowledging the source; patch-writing; providing wrong or incomplete citation or references; presenting or citing the secondary source as a primary source; ghost-writing; purloining; and contract cheating (De Jager and Brown 2010; Ellery 2008; Ellis et al. 2018; Park 2003; Trost 2009; Mahmood et al. 2011; Zafarghandi et al. 2012). The forms mentioned may either be intentionally or unintentionally committed.

For quite a long time, several studies have reported the existence of plagiarism in institutions of higher learning in Anglo-phone countries such as UK, USA and Australia, and there is a growing number of the same from Non-Native English speaking countries such as South American and Asian countries. In Africa, there are also a number of studies that have reported on the existence of plagiarism in institutions of higher learning. For instance, in South Africa (De Jager and Brown 2010; Ellery 2008), in Nigeria (Nordling 2018; Agu and Olibie 2009), and in Botswana (Batane 2010).

Research studies conducted also report some common reasons why students commit plagiarism which include: students' laziness, lack of competency in academic writing and ignorance of plagiarism, flaws in education systems in terms of assessment mode and inconsistencies in applying rules by academic staff (Batane 2010; De Jager and Brown 2010). From the reasons mentioned, it is clear that some students commit plagiarism intentionally while others do so intentionally.

Therefore, caution needs to be exercised when devising strategies to curb plagiarism among students in higher education. Some strategies that institutions of higher learning employ in dealing with plagiarism include: raising awareness about the dangers of plagiarism, taking disciplinary actions against plagiarists, and conducting or teaching students about integrity and what constitutes ethical academic writing (Ellis et al. 2018; Leask 2006; Macdonald and Carroll 2006; Ryan et al. 2009; Ryesky 2007).

Mzuzu University (MZUNI) strongly discourages any form of plagiarism as stipulated in the MZUNI Students Handbook where it warns that students committing such malpractice will face disciplinary action (Mzuzu University 2004). According to Section 2.8.1 of the MZUNI Students Handbook, plagiarism is defined as "unacknowledged use of another person's intellectual materials or ideas" (Mzuzu University 2004: 8). Further, the MZUNI Students Handbook stipulates a step-by-step procedure for handling plagiarism cases. The present study was conducted to explore postgraduate students' knowledge about plagiarism at MZUNI in Malawi.

\section{Problem statement and research questions}

The research problem in this study stems from four key factors. First, one of the researchers was a Masters' degree student in Library and Information Science (LIS) at MZUNI and he observed that most of his fellow postgraduate students have problems in acknowledging the sources they have used in their academic writing. Second, the other two researchers are supervisors of various students pursuing a Masters' degree in LIS and have experienced cases where students exhibit incompetency in attributing ideas they use in their academic assignments. In addition, one of the researchers also works as an Assistant Librarian at MZUNI where he has observed that some postgraduate students' theses contain poor attribution to sources and the list of references 
are poorly prepared or completely omitted. Third, literature shows that students cannot be completely blamed for committing plagiarism because some may commit this academic offence unintentionally (Batane 2010; Mahmood et al. 2011; Zafarghandi et al. 2012). Finally, our thorough search in major library databases reveals that no research has been conducted in relation to plagiarism in higher education in Malawi. This study makes use of these factors to investigate postgraduate students' knowledge of plagiarism at MZUNI in Malawi. In light of the research gap identified, we formulated four research questions to help answer the research problem as follows:

- How knowledgeable are postgraduate students at MZUNI about plagiarism?

- What are the common forms of plagiarism reported to be committed by postgraduate students at MZUNI?

- Why do postgraduate students at MZUNI commit plagiarism?

- What are the actions taken by MZUNI against postgraduate students who plagiarise?

\section{Brief review of related literature}

In order to understand plagiarism, there is a need to understand some rules and standards of academic writing because the literature shows that students commit plagiarism because of their failure to adhere to rules and standards of academic writing. Academic writing is a complicated exercise because it involves summarizing, quoting and paraphrasing other authors' existing or prior ideas (Bailey 2011). Summarizing entails shortening the length of text while retaining the main and important points (Bailey 2011). Quoting entails using a selection of another person's words verbatim (Chang n.d.) whereas paraphrasing is where the author uses their own words to present other authors' ideas without changing the meaning (Bailey 2011). Whenever an author is paraphrasing, quoting or summarising, the source needs to be acknowledged and failure to properly cite or acknowledge the original source is considered plagiarism.

A study by Scouller et al. (2008) which collected data from 135 first year pharmacy students at the University of Sydney investigated students' skills in referencing and citation. The study revealed that although the majority of students rated themselves to be good at referencing and citation, an analysis of their written papers showed failure to cite in-text and write a reference list properly. The study concluded that students overestimated their level of ethical and legal academic writing abilities. The danger with students overrating their academic writing is that they may not appreciate deficiencies in their academic writing abilities, and consequently, they may continue to commit plagiarism unintentionally. Poor understanding of plagiarism on the part of students put them at a higher risk of plagiarising (Leask 2006; Mahmood et al. 2011; Orim et al. 2013; Riasati and Rahimi 2013; Zafarghandi et al. 2012).

Similar findings are reported by other studies which also established poor understanding of plagiarism among students. For instance, a study by Ramzan et al. (2012) found that postgraduate students had a poor understanding of what constitutes plagiarism and as a result, the majority of students admitted that they had plagiarised before. These results suggest that students plagiarised unintentionally due to a lack of knowledge of what constitutes plagiarism.

In view of the several research findings mentioned earlier, it is plausible to accept that plagiarism does exist in higher education but what differs is the level and depth of 
prevalence. In that regard, the higher education stakeholders' focus should be on how to prevent or minimise plagiarism.

Ellery (2008) and De Jager and Brown (2010) have reported a low prevalence of plagiarism in South African universities. However, De Jager and Brown (2010) argue that the low prevalence of plagiarism in South Africa was attributed to under-reporting of plagiarism cases to authorities as established by their study, implying that measuring plagiarism in terms of numbers may sometimes give a false picture.

Park (2003) observed that determining a true picture of the rate of plagiarism poses two challenges: cases of plagiarism are rarely detected and reported; and methods for studying plagiarism might be faulty. Several other authors have measured plagiarism using different methods to determine rates of plagiarism such as subjecting written work to text-matching software (Ledwith and Rísquez 2008; Sheridan et al. 2005), checking disciplinary records (De Jager and Brown, 2010), and self-reporting (Ryan et al. 2009; McCabe 2005; Scouller et al. 2008; Zafaghandi et al. 2012). The present study used a similar approach to that of McCabe (2005) who collected data from both postgraduate students and academics, but the present study went further and collected additional data by conducting follow-up interviews with academics.

In Iran, Zafarghandi et al. (2012) reported high rates of plagiarism among Masters' students in Iranian universities. Zafarghandi et al. (2012) found that the common forms of plagiarism committed by students included paraphrasing without acknowledging sources, omitting quotation marks in directs quotes, patch-writing, and presenting secondary citation as if the original source had been consulted. Similar forms of plagiarism have also been reported in other studies (De Jager and Brown 2010; Leask 2006; Agu and Olibie 2009; Ryan et al. 2009; Trost 2009). The study by Zafaghandi et al. (2012) further revealed that the least prevalent forms of plagiarism among Masters' students in Iranian Universities included ghost writing and purloining.

Some studies have dwelled on investigating the reasons students commit plagiarism. For instance, a study by Zafaghandi et al. (2012) concluded that the majority of students committed plagiarism unintentionally because of poor knowledge of plagiarism by students. According to the literature, students commit plagiarism because of various reasons including pressure to meet deadlines; lack of knowledge among students of what constitutes plagiarism; lack of good academic writing skills; convenience (Internet makes "copy and paste" easy); the high cost of studying; pressure from family; too much academic work; pressure to score high grades; laziness; poor design of assignments by lecturers; and inconsistencies in application of penalties to plagiarists (Batane 2010; De Jager and Brown 2010; Idiegbeyan-Ose et al. 2016; Kwong et al. 2010; Park 2003; Riasati and Rahimi 2013; Ryan et al. 2009).

Some of the ways suggested by Devlin (2006) to curb plagiarism include: the need by universities to set clear definitions of what constitutes plagiarism and the corresponding penalties applied to each plagiarism offence, and putting in place a formal policy on how plagiarism should be handled by all university stakeholders including lecturers, students and administrators. Nonetheless, having the policy and publicising plagiarism through university websites and the students' handbook is not a guarantee that students understand and avoid committing it (Ryan et al. 2009). There is also a need to have dedicated classes aimed at teaching students rules and standards of academic writing. Other researchers such as Roberts (2008), have suggested that lecturers can play a 
greater role in dealing with plagiarism by designing assignments that require students to apply high level writing skills rather than "copying and pasting" thereby making it very difficult for them to plagiarise.

A consensus has been reached in the literature that educating students on good academic writing skills and raising awareness on the negative effects of plagiarism are the best strategies to deal with plagiarism (Leask 2006; Macdonald and Carroll 2006; Pecorari 2010; Walker 2010). Some studies have shown that students continue to commit plagiarism after undergoing such training or classes. For instance, Batane (2010) found that students continued to plagiarise even after being taught about plagiarism and good academic writing. According to Batane (2010), students admitted to have intentionally plagiarised. In that regard, the university applied various punitive measures to plagiarists including withdrawing the student from the university; suspending the student from the university; withholding the student's degree certificate; subjecting the student to academic probation; giving the student a fail grade in the plagiarised course; revoking an already awarded degree from the student upon establishing that the student committed a serious academic offence (Batane 2010). Macdonald and Carroll (2006) suggest the need for a university to consistently define what constitutes plagiarism and to articulate how each form is handled in terms of the depth and the corresponding sanction. Use of text-matching software such as Turnitin is also proving to be helpful in detecting academic work suspected to have been plagiarised.

\section{Theoretical framework}

The social cognitive learning theory developed by Albert Bandura in 1963 underpins this study. The theory explains how behaviour is learned, unlearned and regulated through the interaction of cognitive and environmental or social factors. In the cognitive learning theory, cognitive factors are reciprocal causation, modelling, self-efficacy and self-regulation (Ormrod 2012). Reciprocal causation explains how three variables interact with each other to influence human learning and long-term development (Ormrod 2012).

Modeling explains how behaviour is learned through observation/imitating others such as a teacher demonstrating behaviour and learner imitating (Ormrod 2012). Schunk (2008) reports of a study where students' self-efficacy to perform a particular task increased after observing fellow students succeed in performing a similar task. Self-efficacy is the belief and confidence in one's own capabilities which influences one to engage in certain behaviour (Ormrod 2012).

Environmental or social factors of the cognitive learning theory include reinforcement and punishment (Ormrod 2012). Self-regulation explains how learners develop a sense of appropriate and inappropriate behaviour through direct and vicarious reinforcement and punishments. Reinforcement is "a form of incentive motivation operating through outcome expectations rather than automatic strengtheners of responses" (Bandura 1999:36). Punishment is used to weaken undesirable behaviour (Bandura 1999), which may also be viewed as the opposite of reinforcement. The summary of reciprocal influences, emphasized by Bandura in his theory, which include the personal factors, environmental factors and behavioral factors, is shown in Fig. 1 below. 


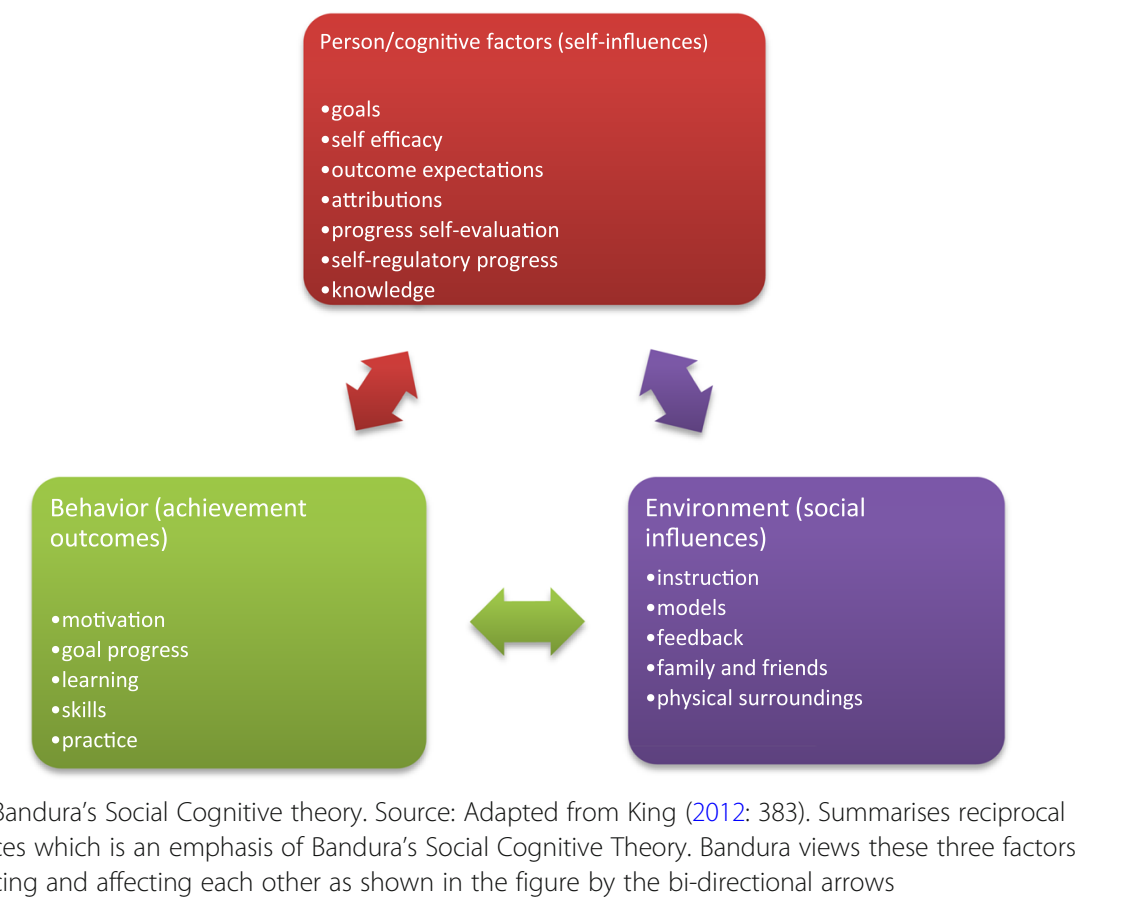

\section{Research design and methodology}

Data for this research were collected from postgraduate students and academics at MZUNI. Purposive sampling technique was used which allowed the researchers to collect data from key informants. A mixed methods approach was adopted in this study. A questionnaire with predominantly closed ended questions was used to collect quantitative data. In total, we self-administered a questionnaire to 87 postgraduate students and 30 academic staff. Qualitative data were collected by conducting follow-up interviews with some academic staff, the assistant registrar and an assistant librarian.

The Statistical Package for the Social Sciences (SPSS) was used to analyse quantitative data from both students and academics. Some frequencies and percentages generated using SPSS were exported to MS Excel to produce charts and MS Word to produce tables. Interviews were recorded using recording applications on HTC One M7 and Iphone 5 smartphones. The recorded interviews were then transcribed using the Trancribe $\odot$ software into MS word. Qualitative data were analysed thematically. The strength of this study is the use of a mixed methods approach which allowed the researchers to triangulate the results. In this context, data collected using questionnaires from students and academic staff were used to confirm each other, and we drew the conclusions of the study based on the findings that were supported most by data sources.

To ensure that the questionnaire was free from errors, its content was subjected to pretesting in two ways. First, we asked experts in research in higher education to comment on the questionnaire focusing on clarity, question wording, validity and order of the questions. Second, we piloted the questionnaire with 10 postgraduate students and 2 lecturers at Kamuzu College of Nursing which is a constituent college of the University of Malawi. Postgraduate students and lecturers at Kamuzu College of Nursing were used in the pilot study because they were similar to the target population of our study. Feedback from education experts and the pilot study was used to make corrections on the questionnaire. 
Ethical issues were addressed in two ways in this study. First, we sought and were granted permission by the Director of Research at MZUNI to conduct the study at MZUNI. We sought permission to conduct this study in Malawi from the National Commission for Science and Technology through its National Committee on Research in Social Sciences and Humanities (NCRSH). Second, before taking part in the study, participants were informed through a consent letter that they were taking part in the study voluntarily. The consent letter further informed participants that even if they had accepted to participate in the study, they were at liberty to withdraw at any stage of the study without giving reasons. The participants signed the consent letter to show that they had read the content and that they were taking part in the study voluntarily.

\section{Results and discussion}

In this section we present, analyse and discuss the findings of the study in line with the research questions guiding the study as follows:

- How knowledgeable are postgraduate students at MZUNI about plagiarism?

- What are the common forms of plagiarism reported to be committed by postgraduate students at MZUNI?

- Why do postgraduate students at MZUNI commit plagiarism?

- What are the actions taken by MZUNI against postgraduate students who plagiarise?

\section{Demographic profiling}

We sent a questionnaire to 87 postgraduate students at MZUNI, of which 53 (60.9\%) questionnaires were returned. Out of 53 students, 52 (98.1\%) were masters students whereas only one $(1.9 \%)$ respondent was a $\mathrm{PhD}$ student. Follow up interviews were conducted with two academics, an assistant registrar (responsible for academics) and assistant librarian (responsible for readers services). Follow-up interviews with an assistant registrar revealed than Mzuzu University is just beginning to introduce $\mathrm{PhD}$ studies and this explains the reason why the study registered only one $\mathrm{PhD}$ student against 52 masters students.

\section{How knowledgeable are postgraduate students at Mzuzu University about plagiarism?}

Since the literature showed that there is no universal definition of plagiarism, we presented students with a list of statements from which they were asked to indicate which statements best describe what they think plagiarism is and is not. Findings revealed that $45(84.9 \%)$ students agreed with the definition of using ideas of someone without citing the original author, 45 (86.5\%) students agreed with the definition of "copy and paste" from books or Internet sources without citing sources and 44 (84.6\%) agreed with the definition of using words of someone without citing the original author (percentages were calculated based on number of respondents of that item). It is a good development that students at MZUNI understand what constitutes plagiarism because according to the theory of social cognitive learning, an aspect of reciprocal causation explains that students' knowledge (cognitive) of what constitutes plagiarism may influence their decision not to plagiarise (behaviour) (see Fig. 1). In fact, Leask (2006) established that 
lack of understanding of plagiarism concepts increases the chances of students plagiarising. It is worrisome though that in this study some students regard paraphrasing, summarising and acknowledging sources as a form of plagiarism. These findings are not unique to MZUNI students because Ryan et al. (2009) found that postgraduate students at the University of Sydney in Australia could select an example of acceptable academic writing as unacceptable while indicating an example of unacceptable writing as acceptable.

Another section required students to rate themselves on their ability to paraphrase, summarise, and cite and reference information sources based on their departmental adopted referencing style. Findings presented in Fig. 2 reveal that students rated themselves as generally good in paraphrasing, summarising, citing and referencing sources. However, it was reported from the interviews with academic staff and the assistant librarian that students were not good at paraphrasing, summarising and citing as evidenced by many errors in their academic assessments and theses available in the library. The study also revealed that the majority of students were not good at citing or referencing using software such as Mendeley and Zotero, as students (67.3\%) self-reported themselves to be either average or poor at citing and referencing using software. Findings from follow-up interviews corroborated the findings from students because the assistant librarian and academic staff confirmed that students are not taught how to cite or reference using software. For example, the assistant librarian commented that

"we don't teach them [postgraduate students]. But yea [yes], as librarians we are supposed to take that lead to teach postgraduate students how to cite using different softwares like Zotero."

The study established that many students plagiarised because they lacked academic writing skills as reported by students and academics, and by analysing reported common forms of plagiarism presented below (which emanate from lack of writing skills) and from follow up interviews. These results give credence to those reported by Scouller et al. (2008) who similarly found that students plagiarised due to lack of skills

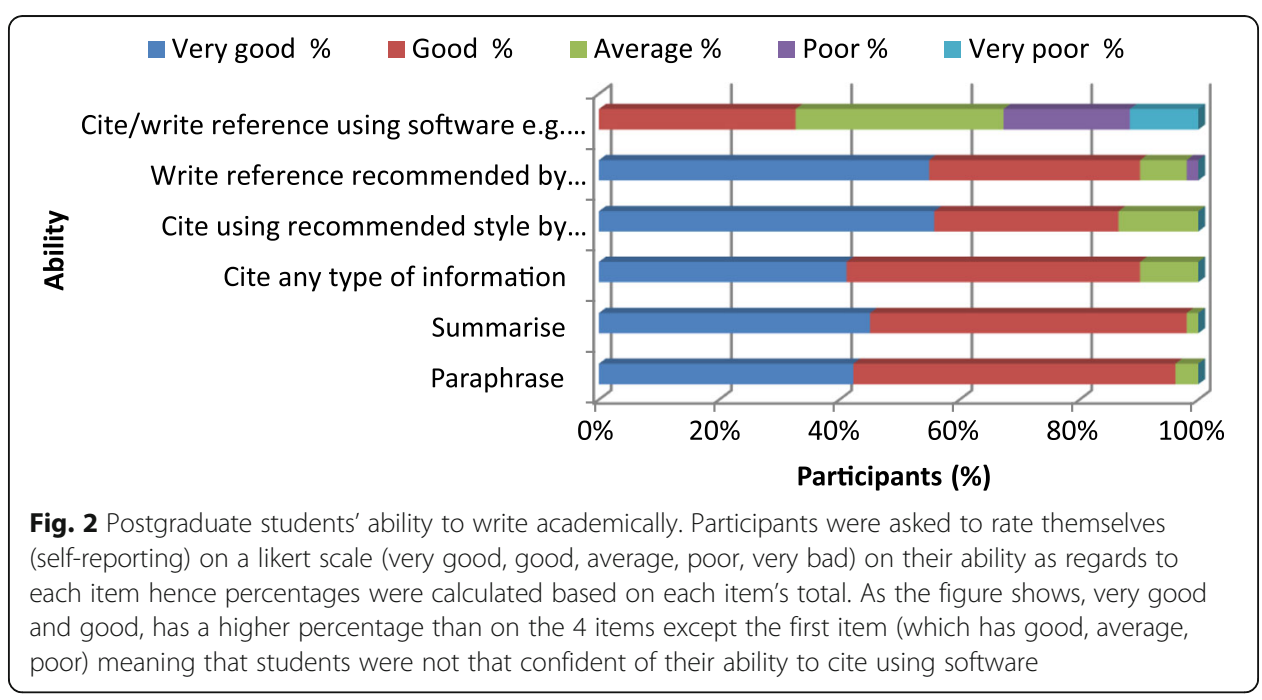


to paraphrase, summarise and reference properly. Like this study, Scouller et al. (2008), and Abdullah and Muhammad (2008) noted that students usually rate themselves as good at academic writing yet they unintentionally committed various forms of plagiarism. In this study, it was observed through follow-up interviews with an assistant librarian and academic staff that students lack good academic writing skills because they were not taught these skills because of a belief that they mastered these skills when they were doing their first degrees. The problem is that MZUNI recruits postgraduate students with diverse backgrounds, that is, from universities that may not have exposed students to good academic writing skills with perhaps a different referencing style from that in a particular department or faculty at MZUNI. In addition, the level and depth of academic writing at postgraduate level is quite different from that required at undergraduate level. Training is important because according to social cognitive learning theory which is informing this study, its element of modeling emphasises the need for guidance which helps transmit language, mores, social practices, and adaptive competencies. Modeling focuses on how well new behaviour is learned when the more experienced demonstrates the activity first then allows the learner to practise (Bandura 1999). In this context, students need to be taught good academic writing skills by academics or librarians because currently, their writing is based on trial-and-error experiences, which according to Bandura (1999) is very costly and unacceptable. Modeling can also be used to make an argument that students will easily learn to use citation software such as Zotero if they are trained or taught by academic staff and librarians.

\section{What are the common forms of plagiarism reported to be committed by postgraduate students at MZUNI?}

The study also sought to understand the prevalence of plagiarism by establishing common forms of plagiarism reported to be committed by students at MZUNI. Data collected using a questionnaire administered to students and academics are presented in Table 1 where it is clear that indeed, students admitted to have committed some forms of plagiarism which were also encountered by academic staff. The study established that prevalent forms of plagiarism reported to be committed by students included: lack of proper acknowledgement after paraphrasing (69.8\%), summarising (64.1\%) and using quotation marks (56.6\%), as shown in Table 1. Students' results are well corroborated by those from the academics' questionnaires results as can be seen in Table 1. Follow-up interviews with some academic staff also confirmed that the common forms of plagiarism committed by students, include using quotation marks without proper acknowledgement, copy verbatim without quotes and proper acknowledgement, "copy and paste" from Internet and submitting others' work as their own. Similar findings were reported by McCabe (2005) who found that a quarter of students admitted to and over two thirds of academics encountered the same forms of plagiarism such as "copy and paste" from written source or web.

These findings mirror what has been reported in other countries by prior studies (Leask 2006; Trost 2009; Agu and Olibie 2009; Vasconcelos et al. 2009; De Jager and Brown 2010; Ellery 2008; Batane 2010; Zafaghandi et al. 2012; Mahmood et al. 2011) which equally found that the common forms of plagiarism committed by students include "copy and paste" without quotes and acknowledging the source; providing incomplete information about the original source; fabricating references; buying already 
Table 1 Common forms of plagiarism reported to be committed by postgraduate students at Mzuzu University

\begin{tabular}{|c|c|c|c|c|c|c|c|c|}
\hline \multirow[t]{3}{*}{ Offences of plagiarism } & \multicolumn{4}{|c|}{ Admitted by students } & \multicolumn{4}{|c|}{ Encountered by academics } \\
\hline & Always & Frequently & Rarely & Never & Always & Frequently & Rarely & Never \\
\hline & $\%$ & $\%$ & $\%$ & $\%$ & $\%$ & $\%$ & $\%$ & $\%$ \\
\hline $\begin{array}{l}\text { Paraphrased work without } \\
\text { acknowledging original author }\end{array}$ & 1.9 & 11.3 & 56.6 & 30.2 & 11.1 & 63 & 18.5 & 7.4 \\
\hline $\begin{array}{l}\text { Summarising text without } \\
\text { acknowledgement }\end{array}$ & 3.8 & 13.5 & 48.1 & 34.6 & 11.1 & 51.9 & 29.6 & 7.4 \\
\hline $\begin{array}{l}\text { Copy text word by word without } \\
\text { acknowledgement }\end{array}$ & 1.9 & 3.8 & 22.6 & 71.7 & 3.8 & 38.5 & 42.3 & 15.4 \\
\hline $\begin{array}{l}\text { Submitted someone's work without } \\
\text { their permission }\end{array}$ & 0 & 0 & 7.5 & 92.5 & 0 & 7.4 & 25.9 & 66.7 \\
\hline Invented or altered data & 0 & 3.8 & 24.5 & 71.7 & 0 & 14.8 & 37 & 48.1 \\
\hline Written an assignment for friend & 0 & 1.9 & 15.1 & 83 & 0 & 12 & 36 & 52 \\
\hline $\begin{array}{l}\text { Using quotation marks without proper } \\
\text { citation or acknowledge }\end{array}$ & 1.9 & 9.4 & 45.3 & 43.4 & 7.7 & 23.1 & 57.7 & 11.5 \\
\hline Invented references or bibliography & 0 & 1.9 & 20.8 & 77.4 & 0 & 7.7 & 42.3 & 50 \\
\hline $\begin{array}{l}\text { Submitted work as an individual } \\
\text { while written as group work }\end{array}$ & 0 & 7.5 & 15.1 & 77.4 & 3.7 & 3.7 & 44.4 & 48.1 \\
\hline $\begin{array}{l}\text { Copy work from internet \& submit } \\
\text { it as your own }\end{array}$ & 0 & 3.8 & 13.2 & 83 & 7.7 & 19.2 & 46.2 & 26.9 \\
\hline
\end{tabular}

written papers; copying from a friend or submitting work done by a friend; patch-writing; and presenting or citing the secondary source as a primary source.

\section{Why do postgraduate students at Mzuzu University commit plagiarism?}

As reported in the previous section, students at MZUNI are reported to have committed various forms of plagiarism. The study established that students plagiarised even though they were aware that plagiarism is a very serious offence in the academic domain. Results showed that the majority of students with scores of $45(88 \%)$ regard plagiarism as a very serious offence whereas six (12\%) students regard plagiarism as serious offence. Other studies have established that the more students see plagiarism as a serious offence the less likely they can commit plagiarism. For example, Zafarghandi et al. (2012) reported that students who perceived plagiarism as a serious offence were less likely to commit it.

The literature section informed this study that students will commit various forms of plagiarism because of various reasons which include laziness, poor time management, lack of good academic writing skills, lack of knowledge of plagiarism, and pressure to score good grades (Idiegbeyan-Ose et al. 2016; Kwong et al. 2010; Resurreccion 2012). Similarly, in this study, findings from students and academic staff established that 32 (62.7\%) students strongly agreed that they plagiarise because of laziness and poor time management, while 29 (54.7\%) students strongly agreed that they plagiarise due to lack of academic writing skills (to cite, paraphrase, summarise or write references), 27 (50.9\%) students strongly agreed that they plagiarise because of pressure to beat assignment deadlines. From these findings, we conclude that students commit plagiarism intentionally and unintentionally. A study by De Jager and Brown (2010) categorised students copying from each other as intentional plagiarism whereas copying without citing sources was categorised as unintentional because students plagiarised due to ignorance or incompetence. Likewise, in this study, we conclude that students who plagiarised because of pressure to beat assignment deadlines, laziness and poor time 
management did it intentionally whereas those who plagiarised due to lack of good academic writing skills did it unintentionally.

It was also revealed during follow-up interviews with academics that students commit plagiarism because most academic staff fail to detect students' acts of plagiarism. This study established, during follow up interviews with academic staff, that lecturers fail to detect every case of plagiarism due to workload because most lecturers handle very big classes within a semester. Ryan et al. (2009) observed that it is difficult for lecturers to detect cases on plagiarism in large classes where students are fond of group based assignments thereby making lazy students benefit from friends without making any contribution. Similar findings were reported at the University of Botswana where Batane (2010) found that students plagiarised after seeing that their friends were not caught and hence concluded that academic staff do not take issues of plagiarism seriously. An environment created by teachers' behaviour can encourage or discourage students' decisions and behaviour (Bandura 1999). This means that if academics create an environment that detects and punishes plagiarism, they can influence students' decision and behaviour not to plagiarise (see Fig. 1 on the interaction of environment factors, behavioral factors and personal factors). This supports environmental and social factors of social cognitive learning theory which states that punishment reduces undesirable behaviour while unpunished behaviour is reinforced (Bandura 1999). Resurreccion (2012) reported that students' plagiarism and cheating in The Philippines decreased when lecturers were watchful of academic misconduct.

Similarly, Batane (2010) found that there was a $4.3 \%$ reduction of plagiarism in students' assignments when they were warned that their assignments would be subjected to Turnitin for plagiarism review. According to the findings of the present study, follow-up interviews with academic staff revealed that MZUNI has very few academic staff who use Turnitin due to lack of awareness. It is, however, worrisome because in this study, 9 (36\%) academic staff still admitted that sometimes some lecturers deliberately ignore plagiarism. Of course other studies such as that of McCabe (2005) found that lecturers occasionally ignored incidents of plagiarism in North American Universities. Another notable reason students resort to plagiarising at MZUNI is the way assignments are designed, that is, assignments are sometimes too easy to plagiarise. This is the reason some higher education stakeholders advocate for the design of assignments that will prevent students to just "copy and paste" but rather they should require students to combine and apply higher level of thinking, analysis and synthesis of other sources (Roberts 2008).

According to the findings, some students indicated that they committed plagiarism because of pressure from work and family pressures. This can be well explained using reciprocal causality as presented in Fig. 1 showing the influence of environmental factors (such as family and friends, office) on behavior. Although the study established that $48(47.5 \%)$ students were on full-time employment, follow up interviews with academics disputed students' claim that they commit plagiarism due to work pressure. Instead, most academic staff were of the view that most students plagiarised because of poor time management and laziness. Elsewhere, Ramzan et al. (2012) found that students plagiarise due to family pressure.

According to follow-up interviews with academic staff, one common reason students commit plagiarism at MZUNI is because of the ease of "copying and pasting" online 
content. Many lecturers observed that students are always under pressure to meet due dates, score good grades or any other pressure and they resort to the content available on the Internet where they just "copy and paste". Many previous studies have explained that the avalanche of information on the internet makes plagiarism conveniently easy and tempting for students (Walker 2008; Klein 2011) and some students will "copy and paste" because they want to save time for other assignments and do other personal things (Batane 2010).

What are the actions taken by Mzuzu University against postgraduate students who plagiarise?

Data gathered from academic staff through a questionnaire showed that the majority of academic staff with a score of 19 (76\%), 13 (54.2\%) and nine (37.5\%) preferred punishing students by giving them a warning, asking the student to rewrite and resubmit an assignment, and giving zero marks or no credit, respectively. The findings are presented in Table 2 where it is also clear that nine (37.5\%) preferred not taking any action against students who committed plagiarism. Follow-up interviews with lecturers showed that they preferred giving students these types of punishments because the cases of plagiarism committed by students were not serious and were not required to be taken to the University's disciplinary committee which has a mandate to suspend or dismiss the student. As already noted, most students committed plagiarism due to lack of academic writing skills and this made lecturers to be lenient to the plagiarists. A comment that follows represents many similar comments made by most academics: “... punishing students for something which they were not taught initially may seem so unfair..." Another comment from an academic agreed that "...as I said already you need to begin to train your students [in good academic writing]...". Similarly, Kwong et al. (2010) noted that academics commonly prefer handling cases of plagiarism without involving the department, faculty or university if the cases are deemed less serious.

During follow-up interviews, some lecturers argued that students may commit serious cases of plagiarism but it is possible that academics fail to detect plagiarism due to workload. In that regard, most academics recommended the use of text-matching software, which in addition to detecting plagiarised academic work, these text-matching software also help students to improve their work before finally submitting to the lecturers. This is an important aspect because according to the Social Cognitive Learning Theory,

Table 2 Actions taken by Mzuzu University to deal with plagiarism

\begin{tabular}{|c|c|c|c|c|c|c|c|}
\hline \multirow[t]{3}{*}{ Sactions/actions } & \multicolumn{4}{|c|}{ Applied by academics } & \multicolumn{3}{|c|}{ Preference by students } \\
\hline & Very commonly & Commonly & Not common & Never & Agree & Disagree & Not sure \\
\hline & $\%$ & $\%$ & $\%$ & $\%$ & $\%$ & $\%$ & $\%$ \\
\hline Give warning & 32 & 44 & 20 & 4 & 88.7 & 7.5 & 3.8 \\
\hline Simply give no credit/marks & 16.7 & 20.8 & 45.8 & 16.7 & 44.2 & 38.5 & 17.3 \\
\hline $\begin{array}{l}\text { Rewrite and resubmit } \\
\text { assignment }\end{array}$ & 16.7 & 37.5 & 41.7 & 4.2 & 75.5 & 15.1 & 9.4 \\
\hline Repeat course & 0 & 16.7 & 54.2 & 29.2 & 34 & 49.1 & 17 \\
\hline Suspension & 0 & 8.3 & 50 & 41.7 & 24.5 & 58.5 & 17 \\
\hline $\begin{array}{l}\text { Expulsion/dismissal from } \\
\text { University/College }\end{array}$ & 0 & 4.3 & 47.8 & 47.8 & 15.4 & 73.1 & 11.5 \\
\hline No action Taken & 20.8 & 16.7 & 25 & 37.5 & 3.9 & 90.2 & 5.9 \\
\hline
\end{tabular}


through the aspect of self-regulated learning, students can develop their own appropriate behaviour through self-management processes of self-observation and judgmental process against performance standards (Woolfolk 2007).

We also asked students to express their views in regard to the ways/actions employed by MZUNI to curb or minimise plagiarism. The findings are presented in Table 2. According to the findings, students preferred lenient punishments and objected to those punishments that jeopardised their academic progression. In more specific terms, $47(88.7 \%)$ students preferred to be given a warning, 40 (75.5\%) students preferred to be asked to re-write and resubmit assignment, and $23(44.2 \%)$ preferred to be given a zero in the plagiarised assignment (students were allowed to select more than one option).

\section{Conclusion and recommendations}

This study has found that students have a conceptual understanding of what constitutes plagiarism, in terms of its definition and forms. According to the study, all students regard plagiarism as a very serious academic offence. However, the study found that students admitted to have intentionally or unintentionally committed plagiarism. According to the study, the common forms of plagiarism reported to have been committed by students included: summarising and paraphrasing without properly acknowledging the source, and using direct quotation without including quotation marks. Students unintentionally committed these forms of plagiarism because they lacked skills in summarizing, paraphrasing and referencing properly. The study also found that students plagiarised intentionally because of laziness and poor time management. The study established that failure by academics to detect and punish plagiarism, due to workload, may have encouraged students to commit plagiarism. One of the more significant findings that emerged from this study is that students committed less serious cases of plagiarism and consequently, students received lenient forms of punishments including warnings and rewriting the plagiarised work. According to the findings, students were more willing to be punished through warning and rewriting their plagiarised assignment because these forms of sanctions did not jeopardise their academic career. Based on the findings we recommend the following to Mzuzu University:

- Introduce advanced training of information literacy to postgraduate students that teach advanced academic writing such as summarising, synthesising and, referencing;

- Make use of text-matching software which should be made compulsory for academics and postgraduate students. Librarians at Mzuzu University should train academics and postgraduate students in the use of referencing softwares such as ZOTERO, Mendeley, Manage sources in Microsoft Word;

- Carry out awareness campaigns about the negative effects of plagiarism to postgraduate students and academics; and

- Encourage academic staff to report cases of plagiarism to the university so that they can be dealt with holistically at institutional level 
Availability of data and materials

Data for conclusions is provided within the manuscript and as supporting files (Figures).

\section{Authors' contributions}

This paper is an extract from an academic research conducted by AS as a requirement for his Master of Library and Information Science at Mzuzu University. WC was the principal supervisor and GD was the co-supervisor. All authors read and approved the final manuscript.

\section{Authors' information}

APATSA SELEMANI is an Assistant Librarian at University of Malawi College of Medicine with 5 years working experience. He holds Master's degree in Library and Information Science from Mzuzu University. His research interests are Intellectual property, Information Literacy, Information behaviour, ICTs in Libraries and Information centers, Knowledge Management and Digital Curation.

E-mail: aselemani@medcol.mw or apatsaselemani@gmail.com

WINNER DOMINIC CHAWINGA is studying for PhD at University of Western Cape in South Africa, and is also a lecturer in the Department of Library and Information Science at Mzuzu University, Malawi, with 5 years' teaching experience at university level. He holds a master's degree in Library and Information Science from the University of the Western Cape (UWC), Bellville, South Africa. His research interests include ICTs in higher education, Web 2.0, e-learning, ICTs in libraries, knowledge management and digital curation.

E-mail: winnchawinga@gmail.com

Gift Alfred B. Dube is the Children's and Outreach Services Librarian and part-time lecturer in the Department Library and Information Science at Mzuzu University. He holds a Master's degree in Library Science and Information services from University of Central Missouri, USA.

E-mail: giftdube1969@yahoo.com or dube.g@mzuni.ac.mw

\section{Competing interests}

The authors declare that they have no competing interests.

\section{Publisher's Note}

Springer Nature remains neutral with regard to jurisdictional claims in published maps and institutional affiliations.

\section{Author details}

${ }^{1}$ College of Medicine Library, University of Malawi, Blantyre, Malawi. ${ }^{2}$ Department of Library and Information Science, Mzuzu University, Mzuzu, Malawi. ${ }^{3}$ Mzuzu University Library and Learning Resource Center, Mzuzu, Malawi.

Received: 2 March 2018 Accepted: 20 July 2018

Published online: 19 September 2018

\section{References}

Abdullah, NA, Muhammad, AM (2008). Are we there yet? ESL postgraduates writing in an English medium. In TWN Biennial Colloquium (p. 10).

Agu NN, Olibie E (2009) Evaluating Students' Plagiarism in Higher Education Institutions. Afr Res Rev 3(4). https://www. ajol.info/index.php/afrrev/article/download/47571/33948

Bailey S (2011) Academic writing: a handbook for international students. Routledge, London; New York Available from: https://s3.amazonaws.com/academia.edu.documents/30231561/batextbook.pdf?AWSAccessKeyld= AKIAIWOWYYGZ2Y53UL3A\&Expires=1533218096\&Signature=1egQ33nDgHs7dPblfUGu8yWYziw\%3D\&responsecontentdisposition=inline\%3B\%20filename\%3DAcademic_writing_a_handbook_for_internat.pdf. Accessed 12 Nov 2015

Bandura A (1999) A social cognitive theory of personality. In: L. Pervin \& O. John (Ed.), Handbook of personality $\left(2^{\text {nd }}\right.$ ed., pp. 154-196). New York: Guilford Publications. (Reprinted in D. Cervone\& Y. Shoda [Eds.], The coherence of personality. New York: Guildford Press). Available from: https://www.uky.edu/ eushe2/Bandura/Bandura1999HP.pdf. Accessed 20 Jun 2016

Batane T (2010) Turning to Turnitin to fight plagiarism among university students. Educ Technol Soc 13(2):1-12

Chang E (n.d.) Quoting, Paraphrasing, \& Summarizing. Available from: https://depts.washington.edu/owrc/Handouts/ Quoting\%20Paraphrasing\%20Summarzing.pdf. Accessed 23 Apr 2016

De Jager K, Brown C (2010) The tangled web: investigating academics' views of plagiarism at the University of Cape Town. Stud High Educ 35(5):513-528. https://doi.org/10.1080/03075070903222641

Devlin M (2006) Policy, preparation, and prevention: proactive minimization of student plagiarism. J High Educ Policy Manag 28(1):45-58. https://doi.org/10.1080/13600800500283791

Ellery K (2008) An investigation into electronic-source plagiarism in a first-year essay assignment. Assess Eval Higher Educ 33(6):607-617 https://doi.org/10.1080/02602930701772788

Ellis C, Zucker IM, Randall D (2018) The infernal business of contract cheating: understanding the business processes and models of academic custom writing sites. Int J Educ Integr 14(1):1

Idiegbeyan-Ose J, Nkiko C and Osinulu I (2016) Awareness and perception of plagiarism of postgraduate students in selected universities in Ogun state, Nigeria. Library philosophy and practice, $0 \_1$

King LA (2012) Experience psychology, 2nd edn. McGraw-Hill, New York

Klein D (2011) Why learners choose plagiarism: a review of literature. IJELLO 7(1):97-110

Kwong T, Ng H, Mark K et al (2010) Students' and faculty's perception of academic integrity in Hong Kong.

Campus-Wide Information Systems 27(5):341-355. https://doi.org/10.1108/10650741011087766 
Leask B (2006) Plagiarism, cultural diversity and metaphor-implications for academic staff development. Assess Eval Higher Educ 31(2):183-199. https://doi.org/10.1080/02602930500262486

Ledwith A, Rísquez A (2008) Using anti-plagiarism software to promote academic honesty in the context of peer reviewed assignments. Stud High Educ 33(4):371-384

Macdonald R, Carroll J (2006) Plagiarism — a complex issue requiring a holistic institutional approach. Assess Eval Higher Educ 31(2):233-245. https://doi.org/10.1080/02602930500262536

Mahmood S T, Mahmood A, Khan M N, et al. (2011) Intellectual property rights: conceptual awareness of research students about plagiarism. Int J Acad Res. 2(6). Available from: http://dx.doi.org/10.7813/2075-4124.2010/2-6/A.29. Accessed 12 Mar 2016

McCabe DL (2005). Cheating among college and university students: a north American perspective. Int J Educ Integr 1(1). Available from: http://dx.doi.org/10.21913/JEl.v111.14. Accessed 12 Mar 2016

Mzuzu University (2004) Students information handbook. Unpublished. Mzuzu: Mzuzu University

Nordling L.(2018). In Nigeria, a battle against plagiarism heats up. Science .360(6396): 1384-1385.DOl: https://doi.org/10. $1126 /$ science. 360.6396 .1384

Orim SM, Davies JW, Borg E, et al. (2013) Exploring Nigerian postgraduate students' experience of plagiarism: A phenomenographic case study. Int J Educ Integr 9(1). Available from: http://dx.doi.org/10.21913/JEl.v9i1.845. Accessed 6 Sept 2016

Ormrod JE (2012) Human Learning, 6th edn. Pearson, Boston

Park C (2003) In other (people's) words: plagiarism by university students-literature and lessons. Assess Eval Higher Educ 28(5):471-488

Pecorari D (2010) Academic writing and plagiarism: a linguistic analysis (Paperback ed.). London: Continuum

Ramzan M, Munir MA, Siddique N et al (2012) Awareness about plagiarism amongst university students in Pakistan. High Educ 64(1):73-84

Resurreccion PF (2012) The impact of faculty, peers and integrity culture in the academe on academic misconduct among Filipino students: an empirical study based on social cognitive theory. Int J Acad Res Bus Soc Sci 2(12):33

Riasati MJ, Rahimi F (2013) Why do Iranian postgraduate students plagiarize? A qualitative investigation. Middle East J Scientific Res 14(3):309-317

Roberts T (ed) (2008) Student plagiarism in an online world. Information Science Reference, Hershey

Ryan G, Bonanno H, Krass I et al (2009) Undergraduate and postgraduate pharmacy students' perceptions of plagiarism and academic honesty. Am J Pharm Educ 73(6):105

Ryesky KH (2007) Part time soldiers: developing adjunct faculty in the war against student plagiarism. B.Y.U Educ Law J (1):119-152. https://digitalcommons.law.byu.edu/elj/vol2007/iss1/5

Schunk DH (2008) Learning theories: an educational perspective (5th ed). Upper Saddle River: Pearson/Merrill Prentice Hall

Scouller K, Bonanno H, Smith L et al (2008) Student experience and tertiary expectations: factors predicting academic literacy amongst first-year pharmacy students. Stud High Educ 33(2):167-178

Sheridan J, Alany R, Brake D-J (2005) Pharmacy students' views and experiences of Turnitin ${ }^{\circledR}$ —an online tool for detecting academic dishonesty. Pharm Educ 5(3-4):241-250. https://doi.org/10.1080/15602210500288977

Trost K (2009) Psst, have you ever cheated? A study of academic dishonesty in Sweden. Assess Eval Higher Educ 34(4): 367-376. https://doi.org/10.1080/02602930801956067

Vasconcelos S, Leta J, Costa L et al (2009) Discussing plagiarism in Latin American science. EMBO Rep 10(7):677-682

Walker AL (2008) Preventing unintentional plagiarism: a method for strengthening paraphrasing skills. J Instruct Psychol 35(4):387-396

Walker J (2010) Measuring plagiarism: researching what students do, not what they say they do. Stud High Educ 35(1):41-59. https://doi.org/10.1080/03075070902912994

Woolfolk A (2007) Educational psychology, 10th edn. Allyn \& Bacon, Boston

Zafarghandi A M, Khoshroo F, and Barkat B (2012) An investigation of Iranian EFL masters students' perceptions of plagiarism. Int J Educ Integ 8(2). Available from: http://dx.doi.org/10.21913/JEl.v8i2.811.

Accessed 20 Jul 2016

Ready to submit your research? Choose BMC and benefit from:

- fast, convenient online submission

- thorough peer review by experienced researchers in your field

- rapid publication on acceptance

- support for research data, including large and complex data types

- gold Open Access which fosters wider collaboration and increased citations

- maximum visibility for your research: over $100 \mathrm{M}$ website views per year

At $B M C$, research is always in progress.

Learn more biomedcentral.com/submissions 